DOI: 10.35218/armca.2019.1.03

\title{
The Hagiographical Icon of Saint Nicholas in the Church of Michael the Brave from Ocna Sibiului. Iconographic, Artistic and Technical Issues
}

\author{
Raluca Marilena Dumitrescu*
}

\begin{abstract}
The article deals with some considerations upon the iconographic, artistic and technical issues that have been identified in the early $18^{\text {th }}$ century hagiographical icon of Saint Nicholas from Transylvania. A description with references to the actual situation of the icon pictures the framework in which not only this object, but also a group of other five other icons that it is part of, is now the focus of attention and conservation-restoration interventions, after they left the original site. After some regards concerning style, author, and technical aspects, as well as the present conservation state of the icon, it has been pointed out the necessity to study these artifacts more thoroughly and investigate them in a scientific way. In this respect, in order to offer a helping hand to the people in charge who started to decipher the inscriptions that give us important information about this icon and also at least another one from the group, the restorer had the role to professionally unveil the texts without any danger to the object. There are presented some intervention made with this aim, and the results that were achieved with some professional aid in the deciphering and translating the writings. Once this information came into light in a more detailed way, the need to identify some chemical features of the materials in the composition of the ensemble, but also some morphological and structural aspects of it became a priority, not only from the perspective of the restoration process had in view, but also for the better knowledge of other research horizons. Thus, the type of investigations that were made are presented, together with their results. The achieved data throws a new light not only upon the Transylvanian icons of the time, but also on future research in a comparative way.
\end{abstract}

Keywords: iconography, hagiographic, icon, inscriptions, investigations, stratigraphy, pigments, restoration

The icon of Saint Nicholas with scenes of his life from Ocna Sibiului (measurements: $33,15 \times 25,19 \times 1,11$ inch), as the group of other five

\footnotetext{
* PhD Student at National University of Arts, "George Enescu” Iaşi, România, email:dumiralu1@yahoo.com
} 
artifacts that belongs to, reported for the first time by Șerban Semo ${ }^{1}$ was found in a storehouse of the Church of Saints Archangels as patrons, erected by the voivode Mihai Viteazu and restored by the voivode Constantin Brâncoveanu. Maybe the situation in which the icons were at that time (the placing into a storehouse and the nailing onto the walls of it with huge spikes) ${ }^{2}$ is owed to the stormy history of this place of worship, which undergone the changes due to the temporary statute as a Unitarian church. According to the supposition of the author, they could belong to the old altar screen of the church $^{3}$ - since at the time of that research in the back of an "ugly catapeteasma from painted planks" that "divided the altar from the rest of the church", was a masonry wall altar screen that also seemed not to be the original one. Though it was specified that the icons - four of them being royal icons, a royal door and a small cross from an altar screen - show differences in dating and style, they could be attached progressively to this altar screen that was considered as vanished, or they could be kept in the church, even with different proveniences or time location. The same author specifies that the royal icons are dating from the first half of the 18-th century, the royal door from the second half, the oldest element being the cross, which dates from the 17-th century. The first two icons, the one of Saint Nicholas and the one that depicts the Archangels Synod, assigned prior by Serban Semo to a presumed master from the south part of the country, they prove to be the work of a Transylvanian one. In the first stage of their research, there was known only the year of the execution: 1724. Due to some later assigns ${ }^{4}$, the icon of Saint Nicholas is signed by Ivan the painter of Rășinari. Besides, it seems that the mural paintings done in the year 1723 in the church from which the icons belong, the adornment of it being „masterly painted and depicting scenes of Jesus the Savior's life, of the principal saints, and also the image of the heaven and hell", are assigned also to his painter.

\footnotetext{
${ }^{1}$ Șerban Semo,Vestigii inedite într-o biserică a lui Mihai Viteazul, in Studii Muzeale, VI, Ed. Muzeului de Artă al R.S.R., București, 1972, pp. 5-11.

2 ibidem, p. 11: „I found some of these were nailed onto the wall with huge spikes, that were penetrated directly through their wood, and the mentioned ones laying down the floor and covered by all sorts of remains (...)"

${ }^{3}$ The author refers to the original altar screen of the church from the time of restoration by Brâncoveanu voivode - see also the note 3, p.11.

${ }^{4}$ Marius Porumb, Un veac de pictură românească din Transilvania, Ed. Meridiane, București, 2003, pl. 95, and Ioana Cristache Panait, „Zugravul Petru din Topârcea” in Artă. Istorie. Cultură, Studii în onoarea lui Marius Porumb, 2003, p. 299.
} 


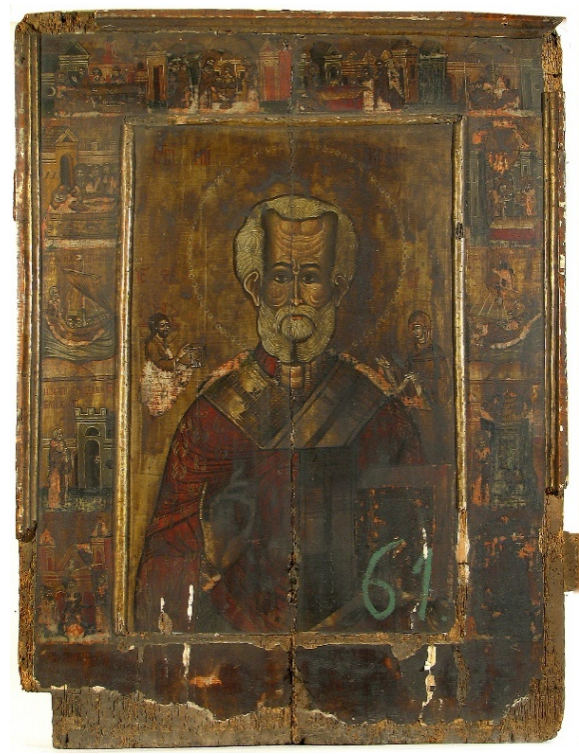

Picture no. 1 Saint Nicholas icon with scenes of his life

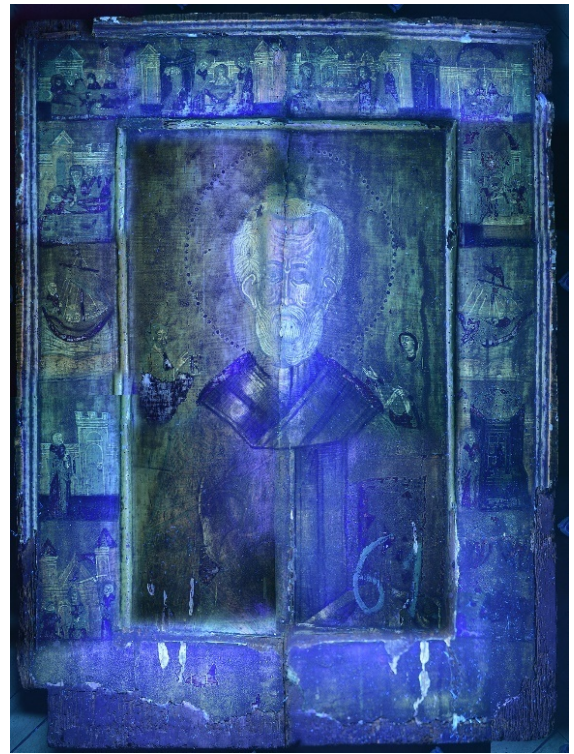

Picture no. 2 UV light analysis

The other two royal icons - The Virgin with Child and Deisis, clearly different form the first ones, are placed at a first study, at the middle or even in the second half of the $18^{\text {th }}$ century ${ }^{5}$, and assigned with a high probability to a north-Transylvanian master. As they have also inscriptions in the lower part, we are hope that in the near future they could offer additional information on the occasion of their restoration.

The royal doors are fitting in the second half of the $18^{\text {th }}$ century, being dated 1770, and their author, according to the opinion of Șerban Semo, should be Pop Porfirie from Rășinari. ${ }^{6}$ We mention that the signature identified in the median area of the left folding door belongs to "Ioan Pop, painter from Rășinari”, according to the publication of Marius Porumb. ${ }^{7}$

\footnotetext{
${ }^{5}$ Marius Porumb, Dicționar de pictură veche românească din Transilvania, sec. XIII-XVIII, p.270, is placing them in the 17 -th century.

${ }^{6}$ it is mentioned, in a thank-you note at the end of the article, the participation of the researcher Marius Porumb at the identification of the inscriptions

${ }^{7}$ Marius Porumb, Dicționar de pictură veche românească din Transilvania, sec. XIII-XVIII, p. 272,193
} 
The oldest element, the cross of the altar screen, is dated in the second half of the 17 th century, ${ }^{8}$ and it is worth a more detailed study; perhaps it would yield new data as for the author but for a more precise dating. The peculiar style of it inclined Marius Porumb to associate it with to nfluences of Western art, the figure of Jesus being identified as a prototype of the representations of pre-Renaissance art, belonging to the Byzantine "mannerism". 9

To come back to present times, it is necessary to mention the fact that this group of icons lies in the collection of icons of the Orthodox Archdiocese of Sibiu, being - after an ample action of conservation and relocation of more objects in a more appropriate space in what concerns the microclimate, at the Conservation-Restoration Department of the same institution - brought to the attention of specialists, researchers of art history, but also expert restorers, some of them already making the subject of some restoration interventions. The icon of the patron saint, representing the Archangels Synod, almost illegible before restoration, and at the moment of the drawing up of this article being in a primarily stage of restoration, shows common features with the one of Saint Nicholas (the format, the profiled rod, the color palette).

The evolution of the restoration process of this later one can uncover new data upon some fragments of inscription not yet deciphered, especially the identification of the author's signature. The icon of Saint Nicholas arose our interest - because of the guidance of Sinigalia Tereza, to which we address our gratitude - for the studying of the eventually kinship in the compositional pattern, stylistically, perhaps even in technique, with its older forerunner from Urisiu de Jos.

In this respect, we mention the framing of this iconographic composition in the "type of a central figure with marginal scenes that is met in Transylvania, since the first half of the $16^{\text {th }}$ century, through Moldavian channel." ${ }^{10}$ As a technical peculiarity of the Transylvanian icons of the $16^{\text {th }}$ century, which are different from the Moldavian manner of treating the panels, where "almost with no exception" the icons have "a more or less wide frame, but always highlighted from the central field", we find here the simple highlighted frame (...)" - under the shape of a rod which separates the

\footnotetext{
${ }^{8}$ according to Șerban Semo, op. cit., p. 11, but also Marius Porumb, Dicționar de pictură veche românească din Transilvania, sec. XIII-XVIII, p. 272, which is placing it even at the end of the 16-th century or at the beginning of the 17-th century, and states that this is the only piece that remained from the old altar screen in the time of the voivod Mihai Viteazul

${ }^{9}$ Marius Porumb, Dicționar de pictură veche românească din Transilvania, sec. XIII-XVIII, p. 272

${ }^{10}$ Ioana Cristache Panait, Zugravul Petru de la Topârcea (Județul Sibiu), in Artă. Istorie.

Cultură, Studii în onoarea lui Marius Porumb, Cluj Napoca, 2003, p.292
} 
central field from the marginal one of the scenes (n. a.), "a feature that shows up to the end of the $16^{\text {th }}$ century." 11

Stylistically, one can observe the Byzantine iconographic features that are sitting at the base of the execution, but also the influence of the patterns from the Constantin Brâncoveanu's period, a balanced color palette, a steady and unconstrained drawing. ${ }^{12}$

We considered a priority the complete deciphering of the Cyrillic inscription at the base of the icon, which constitutes a strange annexation of two texts - one in Slavonic, which seems to represent a moralizing advice, and the other one, in Romanian, which according to Marius Porumb would specify the following: " ... (these) icons were paid by Ionu ... from Vizocna and his wife ... year 7232, 1724". ${ }^{13}$ The same author mentions that the master's signature is merely shown on the pendant icon, the one of the Archangels Synod, where it is specified: "These two icons were made by erei Ivan Pa (inter) ... 1724." 14 It is also of interest - from the perspective of a comparative analysis with other hagiographical icons of the saint in which there can be found similarities - the deciphering of the titles of the marginal scenes, written of Cyrillic letters.

Since the icons from the mentioned group needed a prophylactic operation through the applying of a Japanese paper for the safe transport to the new location, the research of the icon of Saint Nicholas implied an intervention of removing this paper, respectively a consolidation of some small detachment of the paint layer (partially, to the extent that it could be possible to intervene at that moment, following that the icon should be restored in the restoration lab of the Archdiocese). Also, to make the inscriptions legible - the one at the base of the icon and the ones that describe the scenes - it was necessary to undergone an intervention of thinning and a partial release of the deposits as well as the strongly brownish varnish, with clumps in the form of blisters, that have altered the visibility of the ensemble to a large extent.

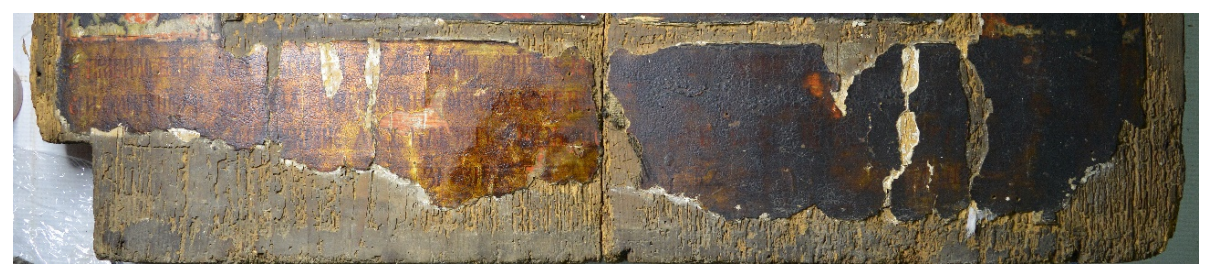

\footnotetext{
${ }^{11}$ Marina Ileana Sabados, Transilvania și școala moldovenească de pictură în secolul al XVIlea. câteva observații, in Artă. Istorie. Cultură, Studii în onoarea lui Marius Porumb, Cluj Napoca, 2003, p.152

${ }^{12}$ Marius Porumb, Dicționar de pictură veche românească din Transilvania, sec. XIII - XVIII, p. 194

13 ibidem, p. 194

${ }^{14}$ ibidem, p. 194
} 
Picture no. 3 The appearance of the inscription at the basis of the icon during the release of the deposits and thinning of the brownish varnish layer

For the identification of some eventual interventions in time upon the icon, it was optically analyzed with the magnifier, but also with UV light. As a result of this analysis, we have noticed that beside some natural ageing processes of degradation of the optical properties of the varnish, respectively some ageing and deterioration processes of the painted layer, in a closed connection to some deterioration of the support, the icon has travelled without any interference from the period of time of its creation to the present. Of course, the degradation linked to a biological attack at the level of the support, by dilatation and contraction - involving changes at the level of paint layer - are visible with the naked eye, and constitute an obstacle in front of the complete reconstitution of some details, especially at the level of the inscription at the basis of the icon.

The text that we could identify over these operations can be presented as it would follow with the generous support of the ethnographer researcher Valerie Deleanu, respectively with a verifying work kindly offered by the priest Vasile Olteanu, the manager of the Museum of Şcheii Brassovului. Interesting is the fact that here it appears the signature of the master (Popa Ivan, the painter from Rășinari), without being specified that the donor (Ion Bo ...), would have had paid the icon (icons) "together with his wife" as it was shown in the previous publications. Also, after the partial removal of the deposits and the thinning of the varnish layer, it could be identified the date 7230 ("from the beginning of the world" n. a.), that would correspond to the year 1721, the late 1722 and not 1724 as it was appreciated before.

\begin{tabular}{|l|l|}
\hline \multicolumn{1}{|c|}{ Slavonic } & Romanian translation \\
\hline $\begin{array}{l}\text { Pravilo vearî i } \\
\text { obru...iaroto...i } \\
\text { zaderjaniu ucitelia iav...gia } \\
\text { g... sta (d)h svoeia } \\
\text {...scel... istina sego radi } \\
\text { vsia jali }\end{array}$ & $\begin{array}{l}\text { (the fairness/truth) of faith and the } \\
\text { rejection of (fall/abys) (lies) in keeping } \\
\text { the spirit of the teacher in the search of } \\
\text { the truth, the joy of its entire desire }\end{array}$ \\
\hline $\begin{array}{l}\text { (v) sei smirenie... m(ă/u) } \\
\text { viso(k)aia inio... etoiu } \\
\text { (b)ogataia o ycena... stia ... } \\
\text { ni ... o ... spa(senie) dșu } \\
\text { nasimu }\end{array}$ & $\begin{array}{l}\text { The whole humbleness ... high ... (of) } \\
\text { this reach teaching (is)... the salvation of } \\
\text { our souls }\end{array}$ \\
\hline
\end{tabular}


the two rows in the Romanian language with Cyrillic letters

\begin{tabular}{|c|c|}
\hline 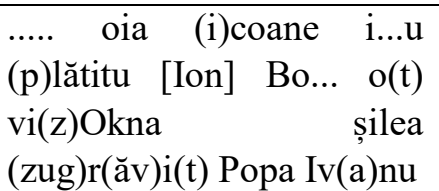 & $\begin{array}{l}\text {.... (i)cons w(er)e (p)aid (by) Ion Bo... } \\
\text { from Vi(z)Okna and were pain }(\mathrm{t}) \mathrm{e}(\mathrm{d}) \\
\text { (by) Popa } \operatorname{Iv}(\mathrm{a}) \mathrm{n}\end{array}$ \\
\hline 31 day $(s)$ & $7230 \quad$ s.....v \\
\hline
\end{tabular}

The texts of the twelve hagiographical scenes have put less problems, even the illegible scene with the dream of the emperor Constantine being identified. In a clockwise reading sense, beginning with the first scene in the upper left corner, we have the following describing titles: rojde stvo (the birth of the saint), creșcenie (the baptism/or the christianization), prinese ego $\mathbf{k}(\mathbf{u} / \mathbf{a})$ ucitele (his receiving of the teaching), sătvori ego(d)iakoni (naming as a deacon), sătvori e..i (naming ...as a priest or bishop, according to iconography), izbavi celoveka moria (the rescue of the man on the sea), ivist $\mathbf{v}$... temniți (the showing up on the jail), ivenie țariuvenie (the showing up [in the dream] of the emperor, according also to iconography), izb(v)i tri kniazi (the rescue of the three voivode), izbavi tri diavi ot bliudosti (the rescue of three maidens from prostitution), posla ih $\mathbf{v}$ Miralikia (the sending to Miralikia), uspenie sti Nikolae (the death of Saint Nicholas).

In connection with the central text of the inscription that refers to the term "viz $\boldsymbol{O c n a " , ~ i t ~ i s ~ n e c e s s a r y ~ t o ~ r e m i n d ~ t h e ~ f a c t ~ t h a t ~ t h e r e ~ i s ~ a ~}$ correspondent in this respect with the inscription from the votive scene in the narthex of the church in Ocna Sibiului, where we find the following words: "Constantine Basarab Brâncoveanu did this church, done y(ear) 1701 and they did painted it year 1723; and being superintendent Popa Ioan from

Vizocnă to this work". 


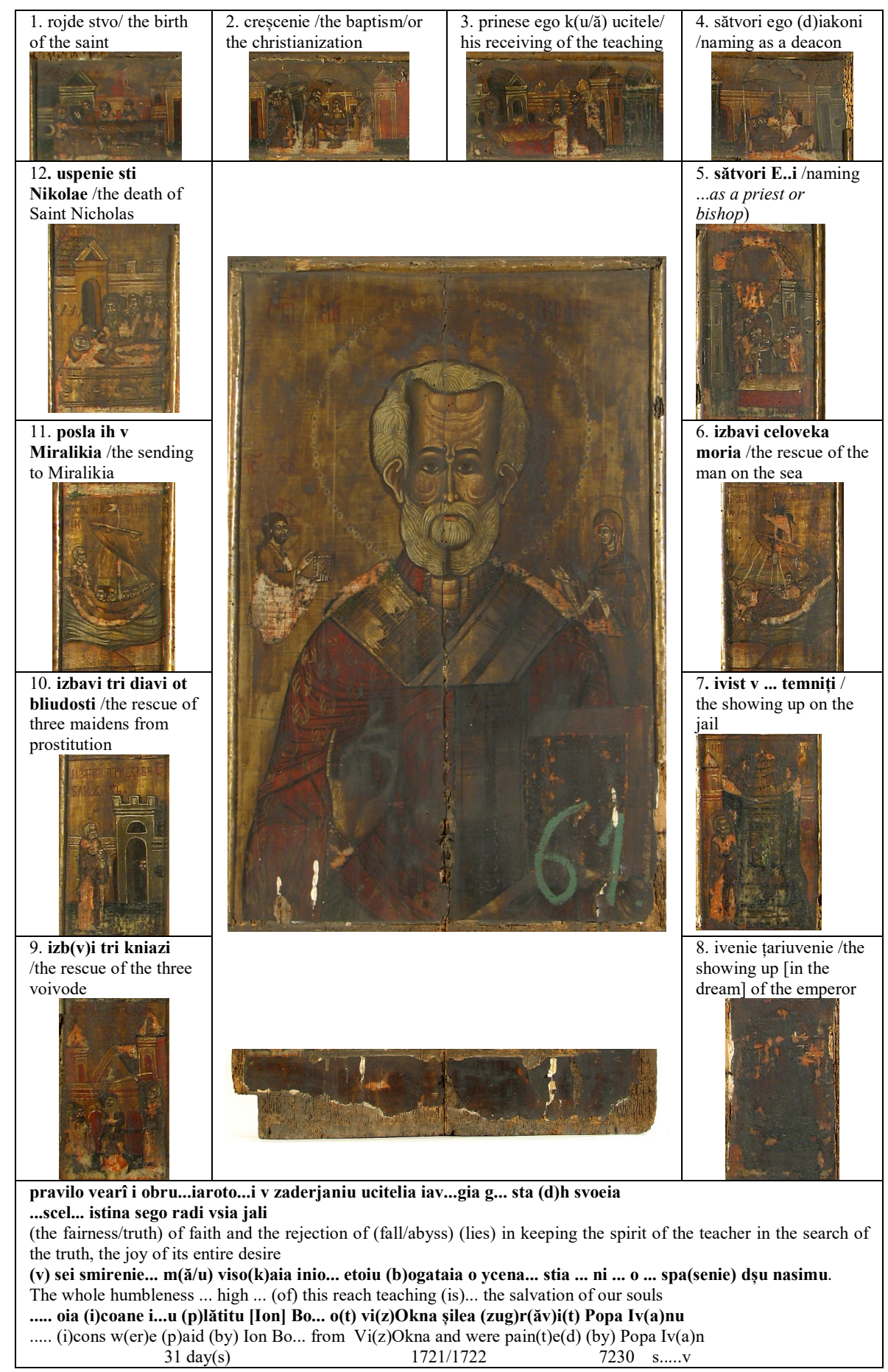


Picture no.4 Detailed images with the deciphering and translation of the inscriptions

If we were to make a parallel - at least in what concerns the titles that are describing the scenes - between this icon and the one of same saint from Urisiu de Jos, one can find some linguistic analogies (from the Slavonic language). The abbreviation Sti (from sveti = saint) is identical for both icons; for the text that describes the nativity, the word rojde is identical with the one from the icon of the $18^{\text {th }}$ century; the words izbavil,temniti, and the preposition $\boldsymbol{o t}$ is found again in the same form.

We can not omit the mentioning of a later glass painted icon that shows obvious similitudes with the icon that we are studying, which maybe served as a model. The homonymous icon is painted by Petru, the painter from Topârcea. Researched by Ioana Cristache Panait ${ }^{15}$, the icon seems to be inspired from the older icon of Ivan ${ }^{16}$, through the compete identification of the scenes of the saint's life, but also through some similarities in composition. The inscriptions attached to the scenes are reproducing from left to right with some small variations in location, the same events in the life of Saint Nicholas: "The birth of Saint Nicholas; The baptism of Saint Nicholas; When thy took him to school; When they named him deacon; When he was made priest; When he saved the three girls; When he saved the sailors from death; When he saved the three voivode of death; When Saint Nicholas was gone to the jail; The death of Saint Nicholas; When (he) sent wheat to Miralichia; When (he) reproved the emperor" 17 It can be seen here - besides the inevitable transposition in the popular style of the glass icon painting, as it would be the reduction of the number of characters, the very sketchy, simplified illustration of the architectures, the stylization of the features etc., similarities in the disposal of compositional elements (as in the nativity scene), or common elements: the small writing slate in the hand of the teacher in the scene of receiving to school, the simplified ciborium and the temple curtain, the building of the jail with the roof and side walls in an opened perspective, the disposal of the head of the father in the arch of a window in the scene of salvation of the three maidens.

\footnotetext{
${ }^{15}$ Ioana Cristache Panait, Zugravul Petru de la Topârcea (Județul Sibiu), p. 292-293

16 ibidem, p 293 - ,, the influence and the closed guiding of youngest Popa Ivan from Rășinari (...) had been observed in the earliest stage one generation earlyer, making the difference between the brush of the father and son.", see also note 63

${ }^{17}$ ibidem, p. 292, and note 61
} 


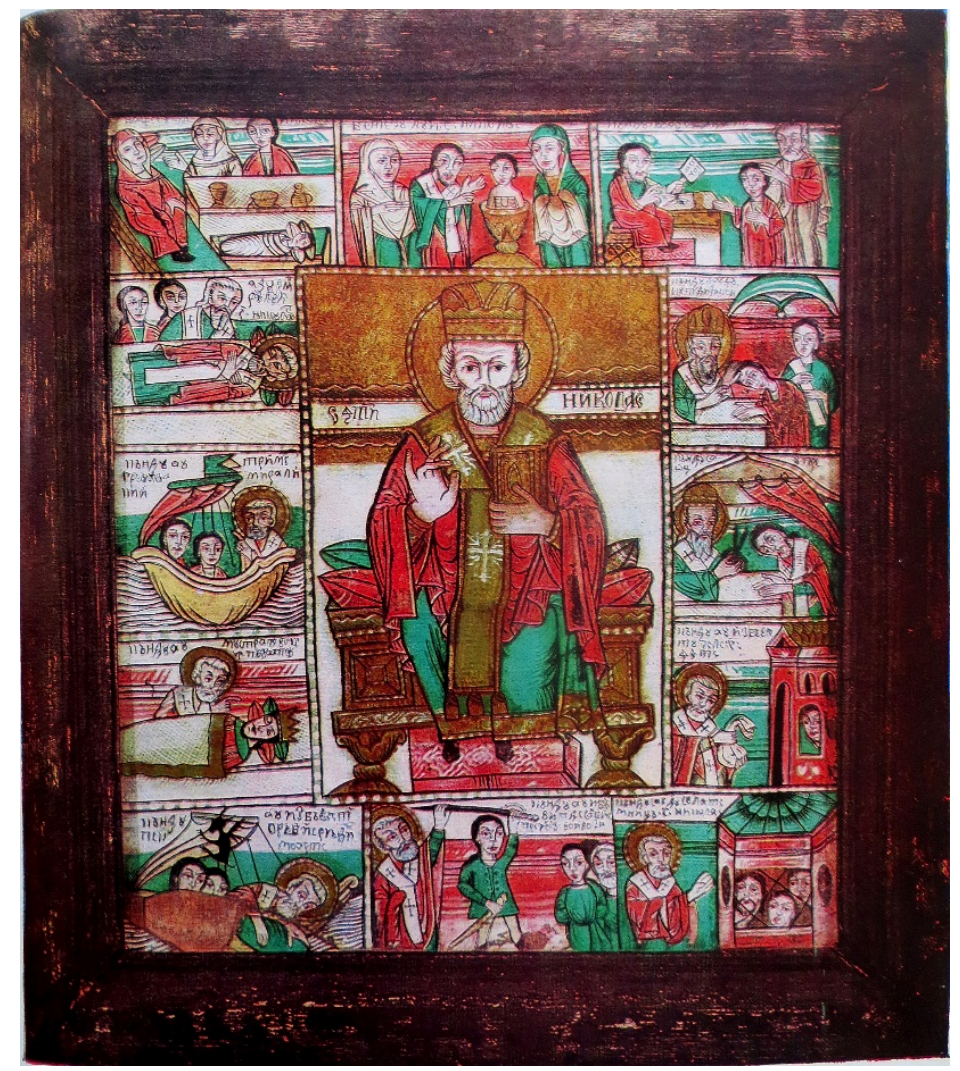

Picture no. 5. Glass icon painting of Saint Nicholas with scenes of his life, painted by Petru the painter from Topârcea (image took from the publication of Iuliana Dancu, Dumitru Dancu, Pictura țărănească pe sticlă, plate no. 101)

An important issue that comes to support the idea of the existence as a model of the homonymous icon of the painter Ivan, is that of through the identification of common traits of this icon, which "totally keeps the qualities of the execution" of a Saint Trinity painted by the same author (signed Petru the painter and dated 1795), could be drawn some conclusions, as for example: the placing of the angels well studied in the Saint Trinity, with their heads graciously inclined, the severe and logical construction of the folds, the perspective noticed in the furniture and in the architectural background cheered up by the crown of a tree, are the expression of a mastery of a style, of a tradition established in the rendering of some shapes that are specific to the wooden painting. ${ }^{18}$

Through the scientific research of the icon, we intended to identify some interventions (UV light analysis), the identification of some pigments

\footnotetext{
${ }^{18}$ Iuliana Dancu, Dumitru Dancu, Pictura țărănească pe sticlă, București , 1975, p. 91
} 
(microchemical tests, XRF analysis), the type of the rendering (microchemical tests), the type of the varnish - supposed as of oil-resin nature (solubility tests, oil test), identification of the composition and appearance of paint layer (stratigraphy).

The UV light analysis revealed with more accuracy the observations made with the naked eye, namely the presence of a natural oil-resinous varnish (through the specific olive-green color), the uneven consistency, with leaks and thick deposits of it, the original appearance of the icon - without later interventions as repaints, chromatic retouch etc.

The test for the identification of the type of rendering yield a result that situates the sample in the area of gesso - the sample did not solve in the chloric acid droplet.

At a first analysis in what concerns the nature of the resin that as used for the varnish, it had been done the test for the presence of oil (for the identification of an oil-resinous varnish). This have given a positive result, with the formation of a stable foam. ${ }^{19}$

Some samples were non-destructively tested, through X-ray spectrophotometry. ${ }^{20}$ The samples no. 1 and 2 proved to have the following composition: cinnabar red on silver leaf. The sample no. 3: cinnabar red with iron ochre and a led pigment; the sample no.4: cinnabar red and a led pigment (in the underlayer); sample no. 5: iron ochre and zinc white (it is suggested a possible repaint because of the presence of this element, though the UV light analysis has not confirmed this) ${ }^{21}$; the samples 6 and 7 contain minium led red. Later on, a new set of investigations with similar results ${ }^{22}$, revealed more precisely the nature of the metallic leaf (silver and a small amount of gold, on a bolus based on iron oxide), the presence of a white pigment for the finishes of the beard of the saint, respectively the mixture of led minium and cinnabar for the tinting of red tones of the architecture. The frame rod was colored with led minium red.

\footnotetext{
19 these former investigations were performed by Dumitrescu Raluca in situ (at the Conservation-Restoration Department of the Orthodox Archdiocese of Sibiu for UV light analysis) and in the restoration lab of the County Museum in Târgu Mureș, on the basis of some micro-sample that were took.

${ }^{20}$ the analysis had been done by dr. Migdonia Georgescu, from the Physico - Chemical and Biological Research Center of National History Museum of Bucharest, Romania, with a portable XRF device, type Innov X Alpha Series 6000, with a wolfram anti-cathode, $U=45$ $\mathrm{kV}, \mathrm{I}=6 \mu \mathrm{A}$ and acquiring time of $60 \mathrm{~s}$

${ }^{21}$ we consider that the presence of zinc is explainable by the heterogeneous composition of the mineral of the career that was taken off, this doesn't necessary indicate the existence of a later intervention

22 analisys undertook by the lecturer and investigator Gheorghe Niculescu at UNARTE, with a portable XRF device, type Bruker Titan, with SDD detector, with a rhodium anti-cathode, a sistem operation in two ways: $45 \mathrm{kV}$ and $10 \mu \mathrm{A}$ for hard elements, and $15 \mathrm{kV}$, respectively 22 $\mu \mathrm{A}$ for light elements, the acquiring time being of $60 \mathrm{~s}$
} 


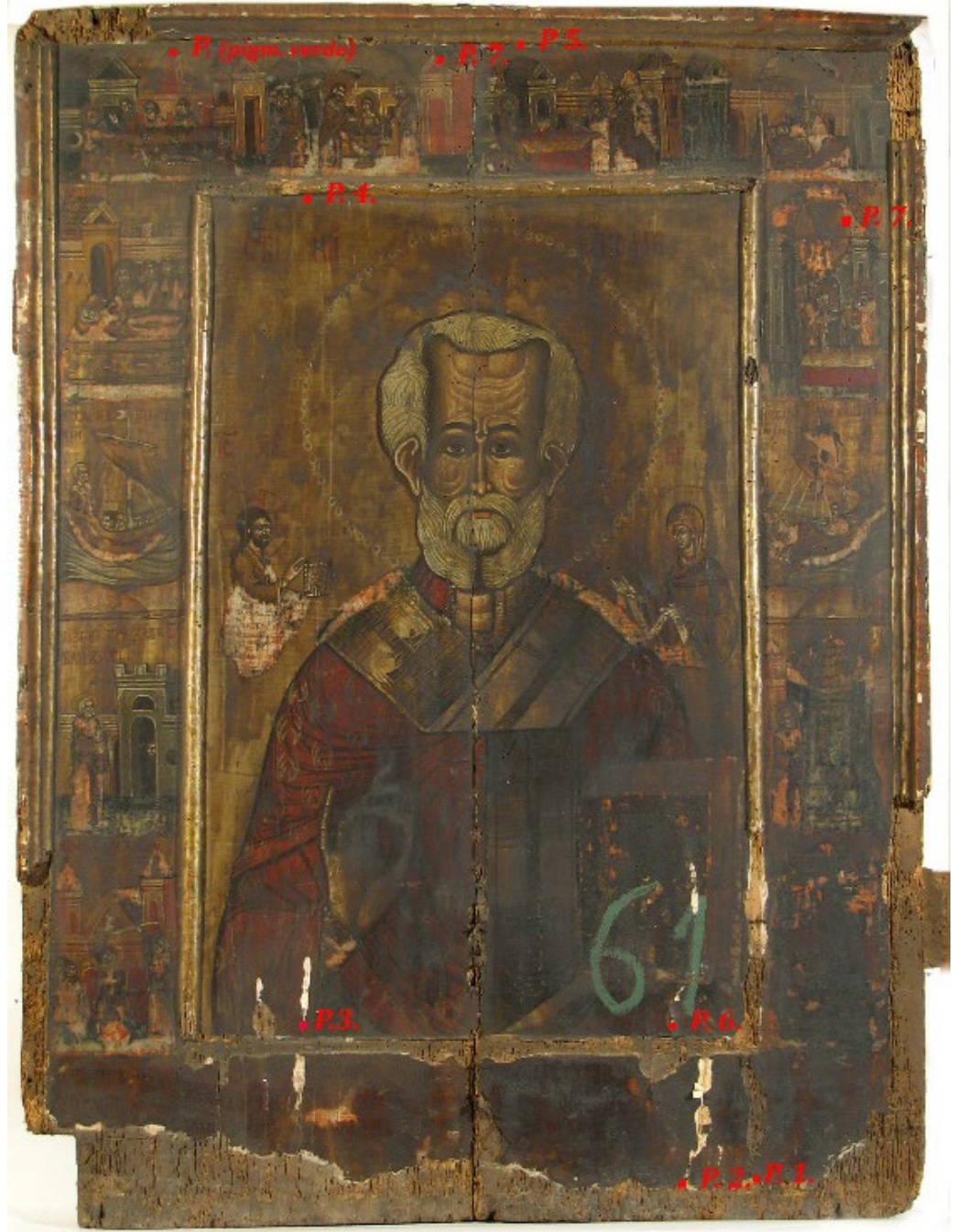

Picture no. 6 The location of the sampling points for analysis

For the completion of these pieces of information, infrared spectroscopy investigations were undertook (FTIR). ${ }^{23}$ For two samples of rendering, taken from different areas, it was identified the presence of

${ }^{23}$ Analysis performed by dr. Cristina Carșote, Physico - Chemical investigation expert at Physico - Chemical and Biological Research Center of National History Museum. The measurements were done by ATR method (Attenuated Total Reflection), with a Bruker Alpha spectrometer, in the spectral domain $4000-400 \mathrm{~cm}-1$, with $4 \mathrm{~cm}-1$ resolution and 32 scanning. To process and evaluate the spectra it was used the software OPUS 7.0. 
gypsum (Figure no.1 "G" for sample no.1), but also of calcium carbonate (Figure no.2, "C" for the sample no.2), according to the comparison with the infrared absorption spectra for these materials. Thus, we identified a rendering layer based on gypsum (gesso), which has calcium carbonate in the composition, which is a habit in the applying of the rendering on medieval icons. ${ }^{24}$ Moreover, at the first set of XRF analysis, calcium was identified in the composition of all the analyzed samples. In what concerns the composition of the varnish layer, it was identified that this contains a natural resin (figure no.2,"R"), through the comparison of the infrared absorption spectra, specific to natural resins from IRUG database (Infrared and Raman Users Group), but also a protein compound (Figure no.2, „AI”, „AII”), which confirm the result formerly obtained for the determination of an oil in the composition of the varnish. Besides these, there have been noticed also compounds from the silicates group (Figure no.2, "S").

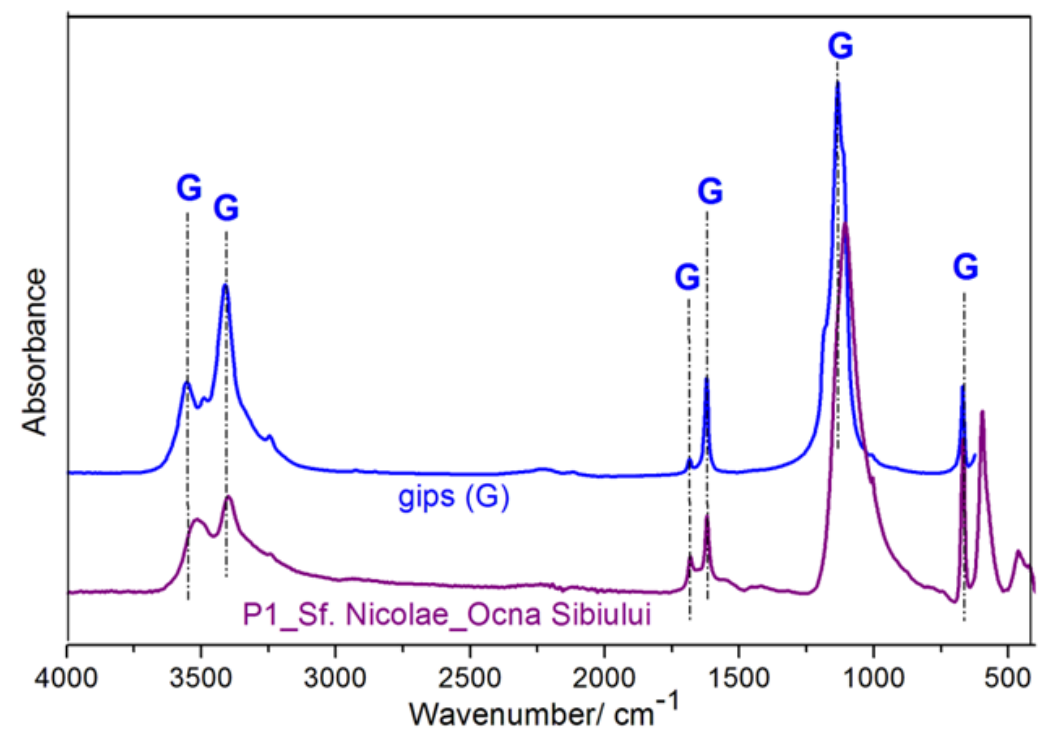

Figure no. 1 The IR spectra of the rendering sample (P1) took from the icon of Saint Nicholas - Ocna Sibiului in comparison with the spectra of gypsum (G), took from the IRUG database (Infrared and Raman Users Group). There are highlighted the main infrared strips typical for gypsum identified in the analyzed sample.

${ }^{24}$ Daniel V. Thompson, The matherials and techniques of medieval painting, Dover Publications, 1956, p.32 


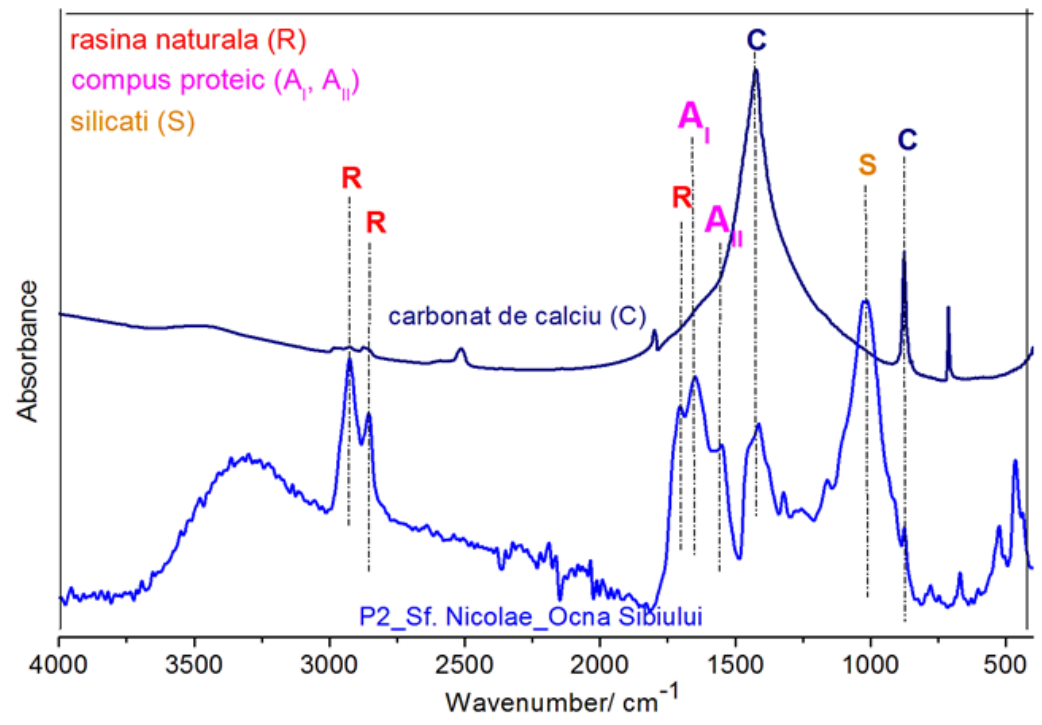

Figure no. 2, The IR spectra of the rendering sample (P2) took from the icon of Saint Nicholas - Ocna Sibiului in comparison with the spectra of calcium carbonate (C), took from the IRUG database (Infrared and Raman Users Group). There are highlighted the main infrared strips typical for calcium carbonate (C), a protein compound (AI, AII), a natural resin (R), and silicates (S).

In conclusion, minium red is repeated in the case of both samples 6 and 7 , and we have supposed (accordingly at the same time with the optical overall examination) the use of the same pigment as an underlayer with the role of bolus for gilding (in this case for the silver leaf, which received the gilded like appearance). This was observed from the beginning by Șerban Semo - "over the rendering is laid down a red color layer, and then gold" 25 (at that time it wasn't investigated the nature of the metallic leaf n. a.). By the way, it is known also that the minium red pigment entered into the composition of the bolus that was used for the preparation of the surface in order to apply the metallic leaf, ${ }^{26}$ here being added the red iron oxide pigment, as the second set of XRF analysis revealed. The details in red cinnabar on silver leaf (P2 at XRF analysis), can originate in the inscription from the basis; the red garment of the saint was obtained from a mixture of red cinnabar with iron ochre and a led pigment - possibly white led, to get a more lighted hue. The metallic leaf - at least supposed initially as gold leaf proved to be in majority silver leaf, with a very small amount of gold (see XRF analysis for P1 and P2, and also the results of the mentioned second set of XRF analysis). Additionally, a small fragment of metallic leaf was

\footnotetext{
${ }^{25}$ Șerban Semo, op. cit., p.7

${ }^{26}$ Ioan Istudor, Noțiuni de chimia picturii, Ed. DAIM Publishing House, București, 2017, p. 123
} 
subjected to the test with nitric acid - in this case, it produced effervescence and the gradually decomposition of the sample. ${ }^{27}$ The presence of the silver leaf on a Transylvanian icon at the beginning of $18^{\text {th }}$ century is explainable, as far as the use of gold in the period in that area was more costly and hard accessible for this reason. ${ }^{28}$ The imitation of the appearance of golden leaf has been done through the tinting of the metallic leaf with a yellow varnish. ${ }^{29}$ The presence of gesso at P1 and calcium carbonate at P2 shows the inhomogeneous rendering layer and doesn't constitute - in our opinion - a reason to suspect a later intervention, all the more so as UV light analysis didn't confirm that, and can be explained by the fact that the gesso-type renderings had calcium carbonate into their composition (see also note 22). This seemingly difference in the composition of rendering can be also the result of the way the sample was taken (it is possible that the sample would have had a cleaved layer). The presence of silicates in the composition of the varnish can be owed to some fine atmospheric particles of dust, embedded in time in its structure.

To corroborate this results with some additional data, it was chosen to use some small fragments that were detached from the paint layer, with the aim of acquiring some stratigraphy. The samples were embedded in Araldite resin $(\mathrm{A}+\mathrm{B})$ and were polished to be analyzed at the microscope. These stratigraphies were very useful in obtaining the identification of the disposal and application order of the color layers, their thickness and composition.

\section{Progressive phases of optical analysis of P1}

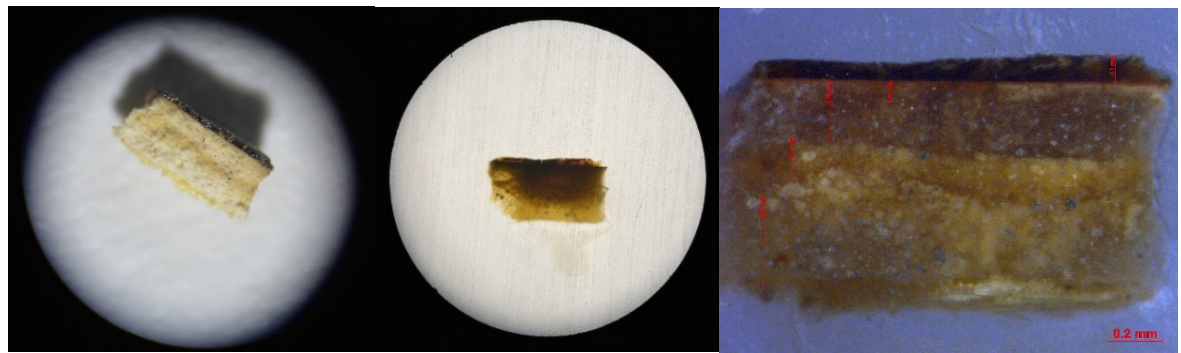

Picture no. $7 \mathrm{P} 1 \mathrm{a})$

P1 b)

P1 c)

P1 a) free observation, with a stereo-magnifier, in direct light - it can be observed the spongy, non-homogeneous structure of the rendering layer, also around three layers of rendering laid down on a yellowish layer (the

\footnotetext{
27 the analysis was performed by Dumitrescu Raluca in the restoration lab of the County Museum in Târgu Mureș, on the basis of a micro-sample that was took

${ }^{28}$ Alexandru Efremov, Icoane româneşti, Ed. Meridiane, Bucureşti, 2003, p. 159

${ }^{29}$ Ioan Istudor, op. cit., p. 125, is mentioning that this has been done ,through the use of some yellow varnishes, tinted with saffron, gum gutti etc."
} 
animal glue used at the preparation of the panel), and then a very thin red layer, followed by the final layer of varnish, brownish and pretty thick.

P1 b) the sample embedded in resin, observation with a stereomagnifier in transmitted light - the spongy structure of the sample is still visible, there are present small particles of impurities, the successive layers of the rendering are less visible, it can be seen the separation between the minium red pigment with metallic leaf and the varnish layer which is slightly translucent, also with impurities.

P1 c) the sample embedded in resin, observation with a microscope, in polarized light - it can be observed the spongy, non-homogeneous structure of the rendering layer (the pores are visible as small white round spots), the stratification with different widths of the rendering, with a yellowish layer at the basis (the animal glue used at the preparation of the panel), five distinct successive application that are thinner towards the surface, a very thin red layer (led minium), the metallic leaf, the brownish and thick layer of varnish. For this stratigraphy there have been done also some measurements: the entire width of the stratigraphy is 880 micrometer $(\mu)$, of which we have successive layers of rendering totalizing $760 \mu$, a width of $20 \mu$ for the red layer and one of $100 \mu$ for the varnish layer.

\begin{tabular}{|l|l|}
\hline & $\begin{array}{l}\text { P2 The statigrapy shows the } \\
\text { disposal and thickness of the } \\
\text { rendering layer, red pigmet, } \\
\text { metallic leaf, and brownish, thick } \\
\text { varnish. Also, it can be observed } \\
\text { the spongy, nonhomogenous } \\
\text { rendering layer (pores visible as } \\
\text { small white round spots) as to P1. } \\
\text { To also determine the thickness of } \\
\text { layers, there have been done some } \\
\text { measurements: the entire width of } \\
\text { the stratigraphy is 573 micrometer } \\
(\mu), \text { the successive layers of } \\
\text { rendering totalizing 453 } \mu, \text { a width } \\
\text { of } 30 \mu \text { for the red layer and one of } \\
90 \mu \text { for the varnish layer. }\end{array}$ \\
\hline Picture no. 8 & \\
\hline
\end{tabular}




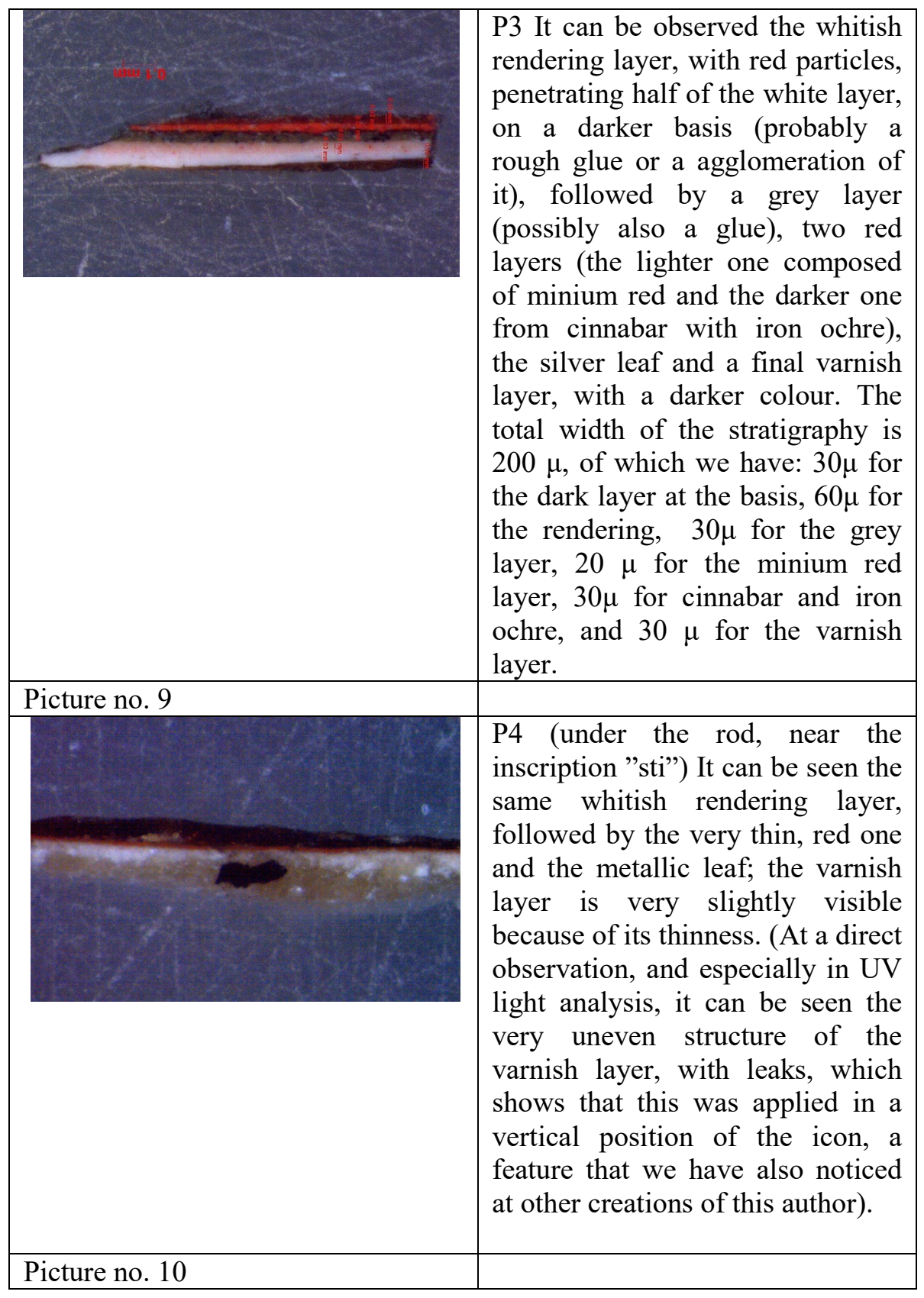




\begin{tabular}{|c|c|}
\hline 9 & $\begin{array}{l}\text { P5 a) Metal leaf (silver and gold) - } \\
\text { at the polarized light analysis, it } \\
\text { can be observed the diffuse gloss } \\
\text { of the particles that have the shape } \\
\text { of yellow-golden flakes. }\end{array}$ \\
\hline \multicolumn{2}{|l|}{ Picture no. 11} \\
\hline & $\begin{array}{l}\text { P5 b) Metal leaf (silver and gold) } \\
\text { - at the polarized light analysis } \\
\text { with the observation of a cross- } \\
\text { section of the sample, it can be } \\
\text { seen again the same diffuse gloss, } \\
\text { but with different chromatic } \\
\text { appearance, of some small silvery- } \\
\text { golden flakes, thus being more } \\
\text { obvious that the metal leaf is } \\
\text { containing more silver. }\end{array}$ \\
\hline \multicolumn{2}{|l|}{ Picture no. 12} \\
\hline & $\begin{array}{l}\text { P6 A thick whitish rendering } \\
\text { layer, not homogeneous (there can } \\
\text { be seen small pores with glue } \\
\text { particles). For this stratigraphy, } \\
\text { measurements have been done: the } \\
\text { entire width of the stratigraphy is } \\
660 \mu \text {, and for approximately three } \\
\text { or four rendering layers with } \\
\text { uncertain boundary, we describe } \\
\text { from bottom to top: } 220,340,70 \\
\text { and } 30 \mu \text {. }\end{array}$ \\
\hline Picture no. 13 & \\
\hline
\end{tabular}




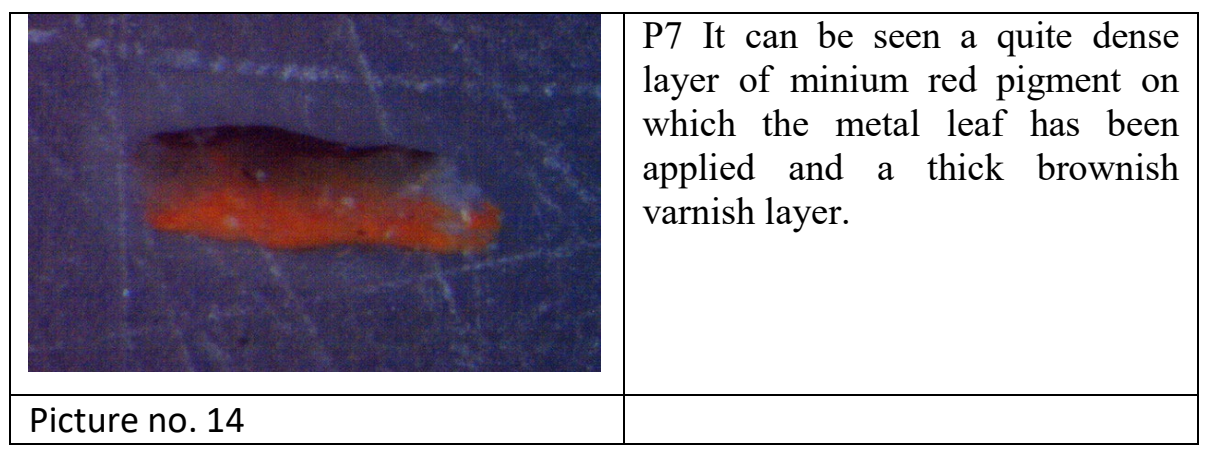

In the end of this study upon the iconographic, artistic and technical issues, with the identification of some chemical features of the materials in the composition of the ensemble in this later case, but also of some morphological and structural aspects, we consider that we achieved to a large extent the aim of a thorough study upon the Transylvanian icon at the beginning of the $18^{\text {th }}$ century. Of course, these pieces of information can be completed with new data, depending on the technical and material means we will have in the future. On this occasion, we address a warm "Thank you!" to all the colleagues that made possible the acquiring of data and information that can be found in this article: Gheorghe Niculescu, Dăneasă Cristina, Maria Modi, Valerie Deleanu, Vasile Oltean, Migdonia Georgescu, Cristina Carşote, Olimpia Coman-Sipeanu, Saveta Pop, Geanina Ionescu and Erika Nemes.

\section{Illustration list:}

Picture no. 1 Saint Nicholas icon with scenes of his life from Ocna Sibiului - photo archive of the Orthodox Archdiocese of Sibiu

Picture no. 2 UV light analysis - photo Raluca Dumitrescu

Picture no. 3 the appearance of the inscription at the basis of the icon during the release of the deposits and thinning the brownish varnish layer - photo Raluca Dumitrescu

Picture no.4 detailed images with the deciphering and translation of the inscriptions - images from the photo archive of the Orthodox Archdiocese of Sibiu

Picture no. 5 Glass icon painting of Saint Nicholas with scenes of his life, painted by Petru the painter from Topârcea (image took from the publication of Iuliana Dancu, Dumitru Dancu, Pictura țărănească pe sticlă, plate no. 101)

Picture no. 6 the location of the sampling points for analysis - a photo processed by Raluca Dumitrescu, from the photo archive of the Orthodox Archdiocese of Sibiu

Picture no. 7 a, b, $\mathbf{c}$ progressive phases of optical analysis of sample no. 1 - photo Raluca Dumitrescu, Nemes Erika

Picture no. 8-14 diverse commented images of some stratigraphy from the icon of Saint Nicholas - photo Nemes Erika 
Figure no. 1 The IR spectra of the rendering sample (P1) - source: Dr. Cristina Carşote from National History Museum, Bucharest, Romania

Figure no. 2 The IR spectra of the rendering sample (P2) - source: Dr. Cristina Carşote from National History Museum, Bucharest, Romania

\section{Bibliography:}

Cristache Panait, Ioana, Zugravul Petru de la Topârcea (Județul Sibiu), în Artă. Istorie. Cultură, Studii în onoarea lui Marius Porumb, Cluj Napoca, 2003

Dancu, Iuliana, and Dumitru Dancu, Pictura țărănească pe sticlă, București, 1975 Efremov, Alexandru, Icoane româneşti, Ed. Meridiane, Bucureşti, 2003

Istudor, Ioan, Noțiuni de chimia picturii, Ed. DAIM Publishing House, București, 2017

Porumb, Marius, Dicționar de pictură veche românească din Transilvania, sec. XIII - XVIII, Ed. Academiei Române, București, 1998

Porumb, Marius, Un veac de pictură românească din Transilvania, Ed. Meridiane, București, 2003, pl. 95 și Ioana Cristache Panait, „Zugravul Petru din Topârcea” în Artă. Istorie. Cultură, Studii în onoarea lui Marius Porumb, 2003

Sabados, Marina Ileana, Transilvania și școala moldovenească de pictură în secolul al XVI-lea. Câteva observații, în Artă. Istorie. Cultură, Studii în onoarea lui Marius Porumb, Cluj Napoca, 2003

Semo, Șerban, Vestigii inedite într-o biserică a lui Mihai Viteazul, în Studii Muzeale, VI, Ed. Muzeului de Artă al R.S.R., București

Thompson, Daniel V., The matherials and techniques of medieval painting, Dover Publications, 1956 